\title{
Economic and environmental effects of double cropping winter annuals and corn using the Integrated Farm System Model
}

\author{
E. J. Ranck, ${ }^{1}$ L. A. Holden, ${ }^{1 *} \odot$ J. A. Dillon, ${ }^{1}$ C. A. Rotz, ${ }^{2} \odot$ and K. J. Soder ${ }^{2} \odot$ \\ ${ }^{1}$ Department of Animal Sciences, The Pennsylvania State University, University Park 16802 \\ ${ }^{2}$ Pasture Systems and Watershed Management Research Unit, USDA Agricultural Research Service, University Park, PA 16802
}

\begin{abstract}
Dairy farms have been under pressure to reduce negative environmental impacts while remaining profitable during times with volatile milk and commodity prices. Double cropping has been promoted to reduce negative environmental impacts and increase total dry matter yield per hectare. Three dairy farms that double cropped winter annuals and corn were selected from northern and western Pennsylvania. Data were collected from recorded crop and dairy records and financial data for 2016 and 2017. Farms ranged in size from 336 to 511 ha with 233 to 663 cows. Data were used to set parameters for the Integrated Farm System Model, which was then used to simulate 8 scenarios for each farm: current operation; 0,50 , and $100 \%$ of corn hectares double cropped; $30 \%$ feed price increase with and without double cropping; and 30\% feed price decrease with and without double cropping at the farm's current level of double cropping. A 20-yr time period, using weather data that was representative of the actual farms, was used in the Integrated Farm System Model simulation to produce both financial and environmental outputs. Double cropping winter annuals and corn silage increased dry matter yield per hectare by $19 \%$, when comparing 0 to $100 \%$ of the corn area double cropped. With all corn land double cropped, net return to management per hundredweight $(45.36 \mathrm{~kg})$ of milk increased by $1.8 \%, \mathrm{~N}$ leached per hectare per year decreased by an average of $4.5 \%$, and phosphorus loss was reduced by an average of $9.2 \%$ across farms. When feed prices increased by $30 \%$, double cropping increased net return over feed cost and net return to management by 1.6 and $2.2 \%$, respectively, across farms. When feed prices decreased by $30 \%$, double cropping decreased net return over feed cost and net return to management by smaller amounts of $0.13 \%$ and $0.11 \%$, respectively,
\end{abstract}

Received August 30, 2019.

Accepted December 4, 2019.

*Corresponding author: lah7@psu.edu across farms. Modeling indicated that double cropping winter annuals with corn silage can have both environmental and economic benefits when winter-annual silage yields are enough to cover expenses.

Key words: double cropping, farm produced feed cost, purchased feed cost, income over feed cost, integrated farm system model

\section{INTRODUCTION}

Increased world population has increased demand for agriculture products (Howarth et al., 2002). Dairy farmers face environmental restrictions, pressure to improve economic efficiency, and volatile milk and feed prices (Rotz et al., 1999; Wolf, 2012; Rotz et al., 2018). Dairy farms have been more profitable when cows per unit of land is large, compared with lesser numbers of cows per unit of land (Rotz et al., 1999). The opposite was true for nutrient cycling. A small number of cows per unit of land improved nutrient recycling with reduced negative environmental impact (Beegle et al., 2002).

Small grain winter annuals, such as rye (Secale cereal L.), triticale ( $\times$ Triticosecale), wheat (Triticum aestivum L.), and barley (Hordeum vulgare L.) can be double cropped with corn silage. Whereas small grain winter annual cover crops are terminated before maturity, double-cropped winter annuals are harvested as grain or used for cattle feed by preserving as silage (Rotz et al., 2002; Borchers et al., 2014) Double cropping can reduce negative environmental impacts by increasing nutrient cycling within the farm and reducing the quantity of feed imported to a farm (Newton et al., 2003). Heggenstaller et al. (2008) reported that double cropping removed 83 and $41 \%$ more $\mathrm{N}$ and $\mathrm{P}$, respectively, when corn silage was double cropped with a winter annual compared with when corn silage was raised as a single crop. Milliron (2016) stated that winter annuals could reduce $\mathrm{N}$ leaching by $70 \%$ and remove an extra 20 to $60 \mathrm{~kg}$ of $\mathrm{N} /$ ha compared with when no winter annual was planted.

Double cropping has the potential to increase profitability of dairy farms by providing increased DM yield 
per hectare and increasing the quantity of manure that can be spread per unit of land on farms with large animal densities (Newton et al., 2003; Brown, 2006; Heggenstaller et al., 2008). In a study in New England, Jemison et al. (2012) reported that total DM yield per hectare of double-cropped winter annual and corn silage was 20 and $33 \%$ greater for winter annuals harvested at the boot and soft dough stage, respectively, compared with a single crop of corn silage.

Winter annual silage was found to be an acceptable forage for many ruminants (Kennelly and Weinberg, 2003). During years when weather allowed for a winterannual silage to be harvested at an earlier maturity, the winter-annual silage could be fed to lactating dairy cows (Harper et al., 2017). Other years when weather conditions delayed harvest and winter-annual silage quality declined, the silage was only acceptable as heifer and dry cow forage (Collar and Gene, 2001).

The challenge to be more profitable while also reducing nutrient losses into the environment requires dairy farms to be more efficient. This forces farmers to make decisions that benefit them economically, while also complying with environmental regulations (Rotz et al., 2018). However, large variations in weather, feed prices, and production systems affect crop and feeding management and are difficult to assess in a short-term study (Rotz et al., 2007, 2018). The Integrated Farm System Model (IFSM) was designed to measure the potential effect of a particular change in management practice on the agronomic, milk production, environmental, and economic outputs of a farm over multiple years of weather (Rotz et al., 2018). The IFSM has been used to evaluate various practices on dairy farms (Rotz et al., 1999; Rotz et al., 2002; Rotz et al., 2007).

Research evaluating the whole-farm economic impact of double cropping winter annuals with corn silage in areas of the United States with shorter growing seasons is limited. Of the studies available, evaluating double cropping systems has been done in areas of the United States with mild winters or small forage plots, and partial budgets have been used to predict the economic impact (Jemison et al., 2012; Hanchar et al., 2015). The objective of this study was to evaluate the effect of double cropping on nutrient cycling, total feed cost, and net return to management as feed prices and the percentage of land double cropped changed. Our hypothesis was that the economic return to double cropping would increase when feed prices or the percentage of double-cropped land increased. We also hypothesized that increasing double-cropped land would reduce $\mathrm{N}$ and $\mathrm{P}$ loss to the environment through reduced leaching and runoff.

\section{MATERIALS AND METHODS}

\section{Data Collection on Case Study Farms}

Three dairy farms that double cropped winter annuals and corn during the years of 2016 and 2017 were selected for the study. These farms were located in northern and western Pennsylvania, where the growing season was relatively short and soils were shallow. Based on the growing season for 2017, growing degree days (GDD) across farms ranged from 1,334 to 1,540. All farms were located in areas where land was not scarce as the cost to rent an acre of farmland averaged $\$ 28$ in 2012, compared with $\$ 196$ in Lancaster County, Pennsylvania (USDA, NASS-Northeastern Region Office, 2013). Farms were visited quarterly during 2017 to gather needed data. Farmer experience in double cropping varied from 3 to 8 yr. Details of the case study farms can be found in the publication by Ranck et al. (2019). Data collection on each farm tracked crop, herd, and financial data during the years of 2016 and 2017. Land double cropped was a combination of winter annual crops and corn. Means and standard deviations were calculated using Microsoft Excel (Microsoft, Redmond, WA).

Crop Data. Land farmed, crops planted, crop inputs and prices, and crop yields were reported by farmers during 2016 and 2017. All winter annual crops received manure at planting or shortly after planting. Farmers reported hauling manure any time field conditions were suitable throughout the year. Farms raised all forage used, except for straw.

Milk Production and Ration Data. Animal numbers, feeding management, and type and size of facilities were recorded for each farm. Cow and heifer numbers were gathered using PCDART, version 7.18.3.0, herd manager software (Dairy Records Management Systems, Raleigh, NC). Milk and component yield and milk income data were gathered from the year-end statements from the milk cooperative of each farm. Ration information was gathered during 2017. The quantity of purchased concentrates in the ration varied by farm, and all farms raised some of the concentrates fed in the ration.

Financial Data. Financial data in the form of income statements or tax returns were obtained from each farm's accountant. Net milk price received per hundredweight (cwt; $45.36 \mathrm{~kg}$ ), annual cost of seed and chemicals, and price of land rent were collected from each farm.

Farm A. Farm A was located at an elevation of 385 $\mathrm{m}$, farmed fields with an average of $12 \%$ slopes, and had 
1,468 GDD during 2017. The farm cropped an average of 511 ha during the years of 2016 and 2017 (Table 1). Hectares of crops grown averaged 263, 223, 48, and 24 for corn, alfalfa and grass hay forage, winter annuals, and other crops, respectively. Crop yields during both years averaged $16.7,9.5,10.2$, and $4.7 \mathrm{t}$ of $\mathrm{DM} /$ ha for corn silage, corn grain, alfalfa and grass hay forage, and winter-annual silage, respectively. Winter annuals were planted as a mixture of winter rye, winter triticale, and winter wheat. The spring of 2017 was wet, so the farm was not able to spread nitrogen on the winter annual crop at green-up. The farm reported spreading $45 \mathrm{~kg} /$ ha of nitrogen fertilizer on the winter annual crop during the spring of 2016 at green-up when the crop was at a growth stage of Feekes 3 to 5. The farm raised all of its forage and corn grain, and reported crop sales both years.

Farm A had an average of 663 cows during the years of 2016 and 2017. Milk production, percent milk fat, and percent milk protein averaged $10,882 \mathrm{~kg} /$ cow per year, $3.58 \%$, and $3.00 \%$, respectively. Farm A raised all of its heifers. Lactating cows and heifers were fed a TMR, and dry cows were fed a combination of hay, silage, and TMR. Winter annual silages were mostly used as heifer feed. Cows were milked 3 times a day in a 28 rotary parlor and housed in a freestall barn bedded with sawdust. The income over feed cost averaged $\$ 6.35 /$ cwt, and the cost of production (COP) of milk averaged $\$ 14.11 / \mathrm{cwt}$.

Farm B. Farm B was located in at an elevation of $588 \mathrm{~m}$, farmed fields with an average slope of $11 \%$, and had 1,334 GDD during 2017. An average of 336 ha was cropped during the years 2016 and 2017. Hectares of crops grown averaged 170,143, 32, and 55 for corn, alfalfa and grass hay forage, winter annuals, and other crops, respectively. Crop yields during both years averaged $8.7,6.4,4.2$, and $2.9 \mathrm{t}$ of $\mathrm{DM} /$ ha for corn silage, corn grain, alfalfa and grass hay forage, and winter-annual silage, respectively. Winter annuals were planted as a monoculture of either winter rye or winter triticale. An average of $107 \mathrm{~kg} / \mathrm{ha}$ of nitrogen was applied on winter annual crops at both years at green-up when the crop was at a growth stage of Feekes 3 to 5 . Farm B was not limited by land and did not report

Table 1. Demographics of 3 dairy farms that double cropped winter annuals and corn in northern and western Pennsylvania

\begin{tabular}{|c|c|c|c|c|c|}
\hline Item & Farm A & Farm B & Farm C & Mean & $\mathrm{SD}$ \\
\hline Cows, no. & 663 & 227 & 223 & 371 & 252.9 \\
\hline Milk production, $\mathrm{kg} /$ cow per yr & 10,882 & 9,966 & 8,891 & 9,913 & 996.6 \\
\hline Milk fat, $\%$ & 3.58 & 3.86 & 3.83 & 3.76 & 0.154 \\
\hline Milk protein, $\%$ & 3.00 & 3.07 & 2.97 & 3.01 & 0.051 \\
\hline \multicolumn{6}{|l|}{ Area farmed, ha } \\
\hline Corn & 264 & 170 & 208 & 214 & 47.3 \\
\hline Forage $^{1}$ & 223 & 143 & 182 & 183 & 40.0 \\
\hline Winter annuals ${ }^{2}$ & 48 & 32 & 55 & 45 & 11.8 \\
\hline Other crops $^{3}$ & 24 & 55 & 24 & 34 & 17.9 \\
\hline \multicolumn{6}{|l|}{ Fertilizer $\mathrm{N}$ applied, $\mathrm{kg} / \mathrm{ha}$} \\
\hline Corn & 160 & 179 & 119 & 153 & 30.7 \\
\hline Winter annuals & 23 & 106 & 64 & 64 & 41.5 \\
\hline Fertilizer $\mathrm{P}$ applied to corn, $\mathrm{kg} / \mathrm{ha}$ & 37 & 31 & 23 & 30 & 7.0 \\
\hline \multicolumn{6}{|l|}{ Crop yield, $\mathrm{t}$ of $\mathrm{DM} / \mathrm{ha}$} \\
\hline Corn, silage & 16.7 & 8.7 & 8.5 & 11.3 & 4.68 \\
\hline Corn, grain & 9.5 & 6.4 & 4.3 & 6.7 & 2.62 \\
\hline Forage & 10.2 & 4.2 & 6.0 & 6.8 & 3.08 \\
\hline Winter annual silage & 4.7 & 2.9 & 2.4 & 3.3 & 1.21 \\
\hline \multicolumn{6}{|l|}{ Crop $\mathrm{COP}^{4} \$ / \mathrm{t}$ of DM } \\
\hline Corn, silage & 115 & 194 & 190 & 166 & 44.5 \\
\hline Corn, grain & 171 & 208 & 273 & 217 & 51.6 \\
\hline Forage & 186 & 338 & 208 & 244 & 82.1 \\
\hline Winter annual silage & 157 & 251 & 301 & 236 & 73.1 \\
\hline IOFC ${ }^{5} \$ / \mathrm{cwt}$ of milk & 6.35 & 3.54 & 1.64 & 3.84 & 2.370 \\
\hline COP,$\$ /$ cwt of milk & 14.11 & 25.55 & 19.76 & 19.81 & 5.720 \\
\hline
\end{tabular}

${ }^{1}$ Forage included both grass and alfalfa crops.

${ }^{2}$ All winter-annual hectares were double cropped with corn. Farm A planted a mixture of winter rye, winter triticale, and winter wheat. Farm B planted some of both winter rye and winter triticale. Farm C planted winter triticale.

${ }^{3}$ Other crops included pasture, soybeans, oats as forage and grain, and barley as forage.

${ }^{4}$ Cost of production or cost to produce a tonne of DM of crop.

${ }^{5}$ Income over feed costs or total milk income minus total feed cost divided by the amount of milk shipped. cwt

$=$ hundredweight $(45.36 \mathrm{~kg})$. 
purchasing forage either year. The farm produced some of its concentrates both years and reported crop sales both years.

Farm B had an average of 227 cows during the years 2016 and 2017. Milk production, percent milk fat, and percent milk protein averaged $9,966 \mathrm{~kg} /$ cow per year, $3.86 \%$, and $3.07 \%$, respectively. All cows and heifers were fed a TMR. Winter annual silages were fed to the cows and heifers, replacing haylage in the ration, for several months of the year. Cows were milked twice daily in a double- 8 herringbone parlor and housed in a freestall barn bedded with sand. Farm B raised all of its heifers. The income over feed cost averaged $\$ 3.54 /$ cwt, and the COP of milk averaged $\$ 25.55 /$ cwt.

Farm C. Farm C was located at an elevation of 391 $\mathrm{m}$, farmed fields with an average slope of $13 \%$, and had 1,540 GDD in 2017. The farm cropped an average of 403 ha during the years 2016 and 2017. Hectares of crops grown averaged 208, 182, 55, and 24 for corn, alfalfa and grass hay forage, winter annuals, and other crops, respectively. Crop yields during both years averaged $8.5,4.3,6.0$, and $2.4 \mathrm{t}$ of $\mathrm{DM} /$ ha for corn silage, corn grain, alfalfa and grass hay, and winter-annual silage, respectively. Winter triticale was the only winter annual grown, with an average of $65 \mathrm{~kg} / \mathrm{ha}$ of nitrogen applied at green-up both years when the crop was at a growth stage of Feekes 3 to 5 . The farm was not limited by land and did not purchase forages during either year. The farm raised some concentrates and reported crop sales both years.

Farm C had an average of 223 cows during the years 2016 and 2017. Milk production, percent milk fat, and percent milk protein averaged $8,891 \mathrm{~kg} /$ cow per year, $3.83 \%$, and $2.97 \%$, respectively. Lactating cows were fed a TMR, dry cows were fed a combination of silage and TMR, and heifers were fed a combination of hay and TMR. Winter annuals silage was fed mainly to heifers. Cows were milked twice a day in a double- 6 herringbone parlor and housed in a freestall barn bedded with sawdust. Farm $\mathrm{C}$ raised all of its heifers. The income over feed cost averaged $\$ 1.64 /$ cwt, and the COP of milk averaged $\$ 19.76 /$ cwt.

\section{IFSM}

The IFSM has the capacity to simulate and predict the major outputs of a dairy farm, including crop yields, milk production, nutrient losses, greenhouse gases, and economic return of various management strategies, as described by Rotz et al. (2007). The model provides a process-level simulation of crop establishment, growth and development, harvest, storage, feeding, milk production, and manure handling (Rotz et al., 2018). Simulated performance is used to predict production costs and the net return to management for the representative farm. Nutrient flows are tracked through the farm system to predict losses to the environment and an overall farm balance of imports and exports of $\mathrm{N}$ and P. Farms can be simulated for up to $25 \mathrm{yr}$ of weather to obtain annual values and longer term average values of farm performance and economic and environmental impacts.

Data from the 3 case study farms were used to set model parameters to represent the farms for the various scenarios in this study. It should be noted that although the farms did harvest corn for grain in some years, when increasing the double-cropping land base to $100 \%$ of corn acres, harvest timeframes would not allow for harvest of corn grain. Therefore, in the 100\%-doublecrop scenario, an excess corn crop harvested would be silage and IFSM would sell corn silage rather than corn grain where needed. Table 1 shows the demographics of the 3 case study farms. Table 2 shows a combination of values per individual farm and IFSM default values used in farm simulations. All inputs changed in the IFSM for each farm were values from a 2-yr average of each farm in 2016 and 2017. Each farm file selected in IFSM was selected to best match each farm. All farms were simulated using a weather file that included 20 yr of historical weather data from a weather station in DuBois, Pennsylvania. Model default values were used for all analyses unless otherwise noted.

Crop Inputs. Rotated cropland was set to a medium loam across all farms, and soil phosphorus level was set to optimum $(30-50 \mathrm{mg} / \mathrm{kg})$. Soil properties included contents of $40 \%$ silt, $25 \%$ clay, and $35 \%$ sand with an available water-holding capacity of $230 \mathrm{~mm}$. For all farms, a small grain crop of rye was double cropped with corn. Other crops grown by farms, such as sorghum $\times$ sudan and oats for grain, were left out of the model due to factors that complicated model setup. The grazing area and total grassland area were set to reflect the quantity of grassland area grazed by each farm. Machine information was entered to reflect the appropriate size and number of equipment of each case study farm.

For tillage, planting, and harvest, the maximum number of operations performed simultaneously was set to 6 and time available for these operations was set to $18 \mathrm{~h} / \mathrm{d}$ to allow maximum use of machinery. All machine operations were set to best match the cropping practices of each farm. The earliest dates for tillage operations and alfalfa seeding were set to April 1 and 15, respectively. For grass seeding, the earliest start date for tillage was set to April 7, and grass seeding was April 20. The earliest starting dates for corn tillage and planting were May 1 and 15, respectively. Corn land also received a sprayer operation on June 15. For small 
grain, the first tillage operation and seeding dates were set to September 12 and 15, respectively.

In IFSM, all field operations and the transport and preservation of feed are simulated through time as influenced by soil properties and weather, and all resources used are included in the costs of production. Dates for harvest processes, including mowing, tedding, raking, chopping (with kernel processing of corn), and harvest, were set the same across farms. Inoculation was not added to silage. Desired quality of forages at harvest were set at 36 and 55\% NDF for each cutting of alfalfa and grass, respectively. Critical NDF for highquality forage was set at $42 \%$ for all forages. Harvest options for both grass and alfalfa were set to wilted silage by chopping, tedding after rain only, and raking before harvest. For alfalfa, the harvest schedule was set to 4 cuttings, mowed at bud stage for each. The earliest harvest date for first-cut alfalfa was set as June 1, with the other 3 cuttings set for $33 \mathrm{~d}$ following the previous cutting. The harvest schedule for grass was 2 cuttings, with early boot stage for the first. The first-cutting harvest date for grass was set for June 10, followed by a second cutting starting $50 \mathrm{~d}$ later. All grass and alfalfa was harvested as wilted silage to provide consistency during modeling. The earliest date for harvesting corn silage was set to September 5. The corn silage cutting height was set to $15 \mathrm{~cm}$, and corn silage kernel processing was used. All grain corn was harvested as dried grain beginning October 15. All small grain was harvested as silage beginning around May 12 .

Storage structures were selected that best represented the types of storage each case study farm used. The capacity of the storage was set to ensure the appropriate amount of silage production for each scenario simulate.

Manure collection and handling methods and the type of bedding used were set to best represent each case study farm. A 6-mo manure storage was used on each farm, with manure applied in the spring and fall before crop establishment.

Animal Inputs. The milking center, cow housing, and heifer housing where selected to best match each farm. Rations were formulated for each animal group to provide a relatively low grain-to-forage ratio. Soybean meal, $44 \%$, and roasted soybean seed were used to meet protein requirements, and corn grain was supplemented to meet energy requirements of each animal group. The target milk production, number of lactating animals, and milking and feeding facilities were set to match those of the case study farms. Facility prices were kept at model default values. Feeding methods for grain, silage, and hay were selected to match each case study farm.

Economic Inputs. Land rental price was reported by each farm, and the values entered for the cost of seed and chemicals were those gathered from each farm. The price of feeds were a 10-yr average during

Table 2. Economic parameters and prices used for the Integrated Farm System Model to represent the 3 dairy farms in northern and western Pennsylvania

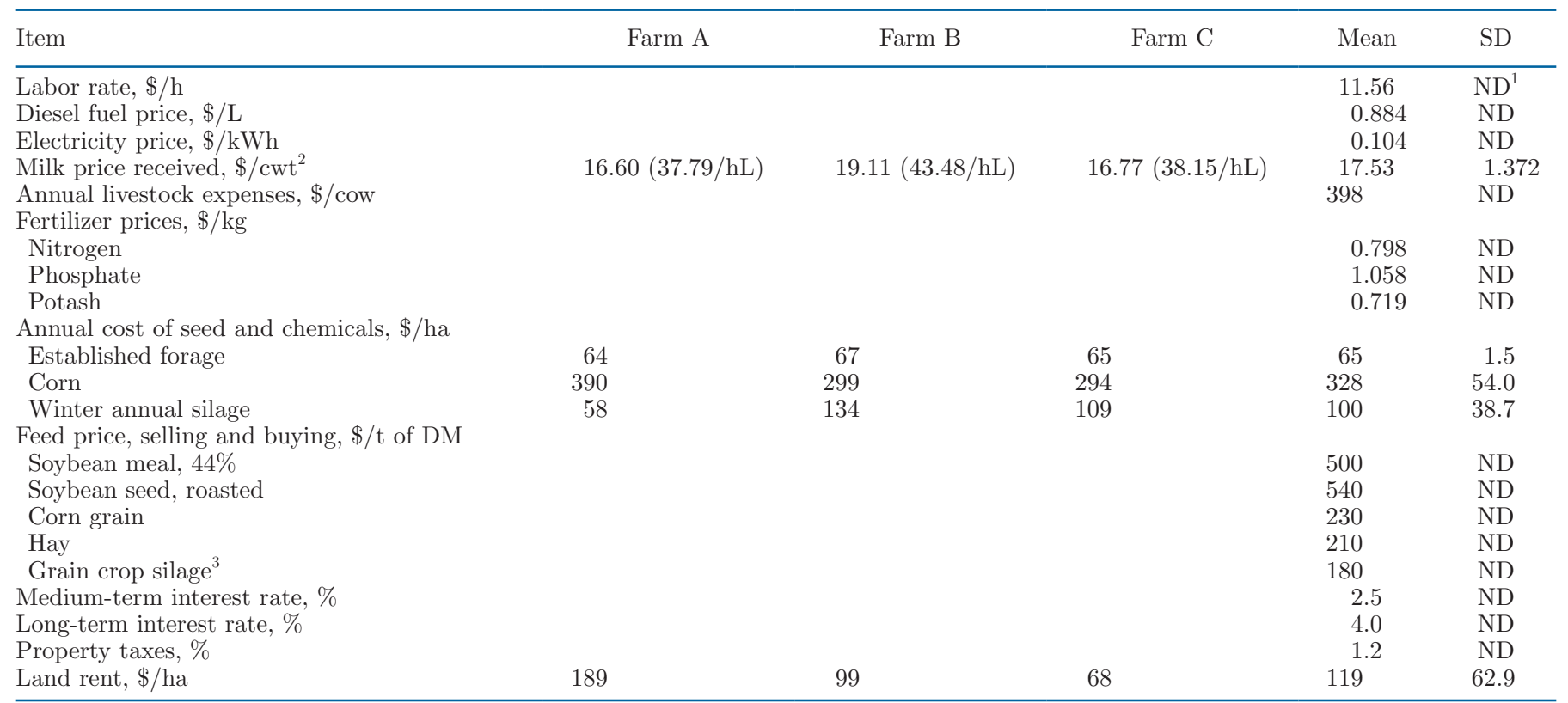

${ }^{1} \mathrm{ND}=$ means were the same across farms.

${ }^{2} \mathrm{cwt}=$ hundredweight $(45.36 \mathrm{~kg})$.

${ }^{3}$ Average price of corn silage and winter-annual silage. 
the years 2008 to 2017 (Table 2), as reported by The Pennsylvania State University Extension (V. A. Ishler, The Pennsylvania State University, University Park, personal communication). Buying and selling prices were set the same at $\$ 500, \$ 540, \$ 230, \$ 210$, and $\$ 180 / \mathrm{t}$ of DM for $44 \%$ soybean meal, roasted soybean seed, corn grain, hay, and grain crop silage, respectively. The price of grain crop silage was the average price of corn silage and winter-annual silage. The value entered for milk was the net milk price received by each farm.

\section{RESULTS AND DISCUSSION}

The yield of hay crop silage remained constant for farm $\mathrm{A}$, with slight changes of -0.83 and $-1.2 \%$ for farms B and C, respectively, as the percentage of corn land double cropped increased (Table 3). One explanation of the differences among the farms seemed to be because the hay crops grown on farms $\mathrm{B}$ and $\mathrm{C}$ included a greater proportion of land in grass forage species and a smaller proportion of alfalfa cropland than farm A. As the percentage of double-cropped land increased, less manure was available to be spread on the hay crops. Since grass cannot fix nitrogen as alfalfa does, less manure spread on the grass hay crops likely decreased the yield for farms B and C.

The yield of grain crop silage from IFSM included both the winter-annual silage and corn silage. Thus, the DM yield of grain crop silage across farms increased by an average of $19 \%$ and ranged from 16 to $23 \%$, when $100 \%$ of the corn land was double cropped compared with no double cropping (Table 3). This was consistent with Borchers et al. (2014), who stated that total DM yield of a double-cropping rotation increased compared with a single crop. In the current study, the increase in DM yield of the double-cropped rotation, compared with corn grown as a sole crop, was below the range of 20 to $33 \%$ reported by Jemison et al. (2012) but greater than the reported 8 to $16 \%$ increase reported by Brown (2006). The total quantity of DM increase per hectare by double cropping played an important role in determining whether it was economically beneficial for a farm. Borchers et al. (2014) stated that if the increase of DM yield with double cropping, compared with a single crop, was not large enough, the added crop yield may not offset the added expense of growing 2 crops on the same land compared with only one crop.

The total grain crop silage in this study increased as the percentage of double-cropped land increased, allowing for more forage to be sold with increasing percentage of double-cropped land across farms (Table 3 ). The quantity of grain purchased by each farm was greatest when $100 \%$ of corn land was double cropped. This was consistent with Rotz et al. (2002), who stated that the energy content of winter-annual silage was less than that of corn silage, so as the farms in this study produced more winter-annual silage, more corn grain was needed to meet the energy needs of cows and young stock.

Equipment cost per tonne of DM of forage produced remained the same for farms $\mathrm{A}$ and $\mathrm{B}$, but increased by $8.5 \%$ for farm $\mathrm{C}$, as double-cropped land increased

Table 3. Changes in crop yield, quantity of forage sold, and grain purchased using the Integrated Farm System Model to simulate increasing percentage of corn land double cropped (DC) on 3 dairy farms in northern and western Pennsylvania

\begin{tabular}{|c|c|c|c|c|}
\hline Item & Current $^{1}$ operation & $0 \% \mathrm{DC}$ & $50 \% \mathrm{DC}$ & $100 \% \mathrm{DC}$ \\
\hline \multicolumn{5}{|l|}{ Farm A } \\
\hline Hay crop silage, ${ }^{2} \mathrm{t}$ of $\mathrm{DM} / \mathrm{ha}$ & 10.0 & 10.0 & 10.0 & 10.0 \\
\hline Grain crop silage, $^{3} \mathrm{t}$ of DM/ha & 17.6 & 16.9 & 18.5 & 19.9 \\
\hline Forage sold of that produced, ${ }^{4} \%$ & 42 & 40 & 45 & 49 \\
\hline Grain purchased, ${ }^{5} \mathrm{t}$ of DM/cow per yr & 3.02 & 3.02 & 3.01 & 3.11 \\
\hline \multicolumn{5}{|l|}{ Farm B } \\
\hline Hay crop silage, $\mathrm{t}$ of DM/ha & 3.9 & 3.9 & 3.9 & 3.9 \\
\hline Grain crop silage, t of DM/ha & 9.2 & 8.8 & 9.8 & 10.8 \\
\hline Forage sold of that produced, $\%$ & 34 & 31 & 38 & 44 \\
\hline Grain purchased, t of DM/cow per yr & 3.17 & 3.14 & 3.23 & 3.37 \\
\hline \multicolumn{5}{|l|}{ Farm C } \\
\hline Hay crop silage, $\mathrm{t}$ of $\mathrm{DM} / \mathrm{ha}$ & 6.0 & 6.0 & 5.9 & 5.9 \\
\hline Grain crop silage, t of DM/ha & 9.0 & 8.5 & 9.3 & 9.9 \\
\hline Forage sold of that produced, $\%$ & 51 & 49 & 53 & 56 \\
\hline Grain purchased, $t$ of $\mathrm{DM} /$ cow per yr & 2.90 & 2.87 & 2.94 & 3.07 \\
\hline
\end{tabular}

${ }^{1}$ Average farm parameters entered into the Integrated Farm System Model for each farm during 2016 and 2017.

${ }^{2}$ Forage included both grass and alfalfa crops.

${ }^{3}$ Winter annual and corn silage.

${ }^{4}$ Hay crop or grain crop silage.

${ }^{5}$ Dry shelled corn. 
Table 4. Changes in crop production cost per tonne of DM of forage produced using the Integrated Farm System Model to simulate increasing percentage of corn land double cropped (DC) on 3 dairy farms in northern and western Pennsylvania

\begin{tabular}{|c|c|c|c|c|}
\hline Item & Current $^{1}$ operation & $0 \% \mathrm{DC}$ & $50 \% \mathrm{DC}$ & $100 \% \mathrm{DC}$ \\
\hline \multicolumn{5}{|l|}{ Farm A } \\
\hline Equipment cost ${ }^{2} \$ / \mathrm{t}$ of DM & 15 & 15 & 15 & 15 \\
\hline Fuel and electric cost, $\$ / \mathrm{t}$ of $\mathrm{DM}$ & 9 & 9 & 9 & 9 \\
\hline Labor cost, $\$ / \mathrm{t}$ of $\mathrm{DM}$ & 8 & 8 & 8 & 8 \\
\hline Seed, fertilizer, and chemical cost, $\$ / \mathrm{t}$ of $\mathrm{DM}$ & 31 & 31 & 30 & 30 \\
\hline Hay crop silage, $\$ / \mathrm{t}$ of $\mathrm{DM}$ & 85 & 85 & 85 & 84 \\
\hline Grain crop silage, $\$ / \mathrm{t}$ of $\mathrm{DM}$ & 78 & 77 & 82 & 88 \\
\hline \multicolumn{5}{|l|}{ Farm B } \\
\hline Equipment cost, $\$ / \mathrm{t}$ of DM & 52 & 53 & 52 & 53 \\
\hline Fuel and electric cost, $\$ / \mathrm{t}$ of $\mathrm{DM}$ & 5 & 5 & 5 & 5 \\
\hline Labor cost, $\$ / \mathrm{t}$ of $\mathrm{DM}$ & 9 & 9 & 9 & 9 \\
\hline Seed, fertilizer, and chemical cost, $\$ / \mathrm{t}$ of $\mathrm{DM}$ & 60 & 59 & 62 & 66 \\
\hline Hay crop silage, $\$ / \mathrm{t}$ of $\mathrm{DM}$ & 170 & 172 & 170 & 170 \\
\hline Grain crop silage, $\$ / t$ of $D M$ & 127 & 123 & 134 & 147 \\
\hline \multicolumn{5}{|l|}{ Farm C } \\
\hline Equipment cost, $\$ / \mathrm{t}$ of $\mathrm{DM}$ & 25 & 25 & 26 & 27 \\
\hline Fuel and electric cost, $\$ / \mathrm{t}$ of $\mathrm{DM}$ & 11 & 11 & 12 & 13 \\
\hline Labor cost, $\$ / \mathrm{t}$ of $\mathrm{DM}$ & 14 & 14 & 15 & 16 \\
\hline Seed, fertilizer, and chemical cost, $\$ / \mathrm{t}$ of $\mathrm{DM}$ & 37 & 35 & 39 & 43 \\
\hline Hay crop silage, $\$ / \mathrm{t}$ of $\mathrm{DM}$ & 88 & 90 & 87 & 86 \\
\hline Grain crop silage, $\$ / \mathrm{t}$ of $\mathrm{DM}$ & 107 & 99 & 114 & 133 \\
\hline
\end{tabular}

${ }^{1}$ Average farm parameters entered into the Integrated Farm System Model for each farm during 2016 and 2017.

${ }^{2}$ For each farm, equipment costs include custom operating expenses.

(Table 4). This cost per tonne of DM of forage produced includes hay and grain crops harvested as a forage. Borchers et al. (2014) stated that one of the benefits of double cropping was that a greater proportion of fixed costs of equipment were spread over greater crop yield. However, in the current study, double cropping increased variable costs such as equipment repairs and maintenance, possibly explaining why the equipment costs per unit of forage produced remained the same or increased, rather than decreasing as stated by Borchers et al. (2014).

Farm B had the greatest equipment expense of all farms at $\$ 53 / \mathrm{t}$ of DM of forage produced for $100 \%$ corn land double cropped, compared with $\$ 15$ and $\$ 27 / \mathrm{t}$ of $\mathrm{DM}$ of forage produced on farms A and C, respectively (Table 4). This large equipment expense for farm B was likely due to farm B harvesting almost all forage by a custom operator, whereas farms $\mathrm{A}$ and $\mathrm{C}$ reported less custom expenses. Custom operations would also include other costs, such as fuel and operator labor. Farm B spent less for fuel and electricity per tonne of forage produced than farms A and C, because some of these expenses were included under custom operation expense.

The cost of seed, fertilizer, and chemicals per unit of forage produced by each farm decreased by $2.5 \%$ for farm A but increased by 12 and $22 \%$ for farms B and $\mathrm{C}$, respectively, as double-cropped land increased from 0 to $100 \%$. This means that farm A spent less for seed, fertilizer, and chemicals for the winter-annual silage per unit of forage, compared with other farm forages, such as corn silage and hay crops. The combination of the lower yields of the winter-annual silage and the greater amounts of $\mathrm{N}$ fertilizer by farms $\mathrm{B}$ and $\mathrm{C}$, compared with farm A, is likely 2 of the reasons for the greater cost for winter-annual silage by farms B and C (Table $1)$.

The COP per unit of hay crop silage was reduced by $1.3,1.7$, and $3.6 \%$ for farms A, B, and C, respectively, when $100 \%$ of the corn land was double cropped compared with corn alone. This decrease in hay crop silage across farms was likely due to certain fixed costs, such as land rent and crop storage, as well as variable costs, such as manure hauling, being spread across more crop DM. Although the decrease in the COP per unit of hay crop silage was small, it shows that double cropping can have a positive economic impact to a farm, outside of increasing total forage production. This agreed with Borchers et al. (2014), who stated that double cropping may spread certain fixed costs across more crops.

The COP per tonne of DM increased numerically for grain crop silage across farms as double-cropped land increased from 0 to $100 \%$ of corn land (Table 4). Crop yield and the production cost per unit of land are the main components that drive COP. The relationship between yield and the COP of a crop can be seen when looking at yields of crops across farms in this study (Table 3) and may partially explain why farm A had the smallest COP. Corn silage yields were greater than the winter-annual silage yields, so the cost of pro- 
duction could be spread over more forage for the corn silage compared with the winter-annual silage. One of the primary reasons for double cropping was to reduce feed costs. If double cropping were to cause the COP of grain silage to increase above the purchased price of grain crop silage, than double cropping would cause a farm to operate at a loss, as compared with simply purchasing the grain crop silage or complementary forage. During the time of this study, the 10-yr average price for purchased grain crop silage was $\$ 180 / \mathrm{t}$ of DM (V. A. Ishler, The Pennsylvania State University, University Park, personal communication). All of the farms were able to produce grain crop silage for less than $\$ 180 / \mathrm{t}$ with the highest cost being $\$ 170 / \mathrm{t}$, even when $100 \%$ of the corn land was double cropped, which made double cropping an economically viable endeavor for these simulated farms.

The rate at which the COP of the grain crop silage increased as double-cropped land increased was not the same across farms, indicating that both the yields of corn silage and winter annuals and costs to produce these crops varied across farms. Farm A had the largest crop yields (Table 3) and the smallest COP of crop produced (Table 4) in the study. When farm A was simulated with no double cropping or all corn double cropped, the COP per tonne of DM of grain crop silage increased by $15 \%$. However, for the same comparison, the COP of grain crop silage increased by 20 and $34 \%$ for farms B and C, respectively, indicating efficiency of double cropping was greatest for farm A, then farm B, followed by farm C.

Table 5 reports the whole-farm balance of $\mathrm{N}$ and $\mathrm{P}, \mathrm{N}$ and $\mathrm{P}$ loss, percentage of $\mathrm{P}$ removed of that applied, and erosion loss. The balance of $\mathrm{N}$ and $\mathrm{P}$ was calculated by taking the kilograms of $\mathrm{N}$ and $\mathrm{P}$ imported per hectare and subtracting that exported. The net balance of $\mathrm{N}$ and $\mathrm{P}$ was the amount of $\mathrm{N}$ and $\mathrm{P}$ that could enter the environment as pollution. Net $\mathrm{N}$ ( $\mathrm{kg} / \mathrm{ha}$ ) changed by $-2.0,20,32 \%$ for farms A, B, and C, respectively, when $100 \%$ of the corn land was double cropped compared with none. Nitrogen leached, kilograms per hectare per year, changed by $-36,8.8$, and $14 \%$ for farms $\mathrm{A}, \mathrm{B}$, and $\mathrm{C}$, respectively, when $100 \%$ of corn land was double cropped compared with none. In the current study, net $\mathrm{N}$ balance and $\mathrm{N}$ leached $(\mathrm{kg} / \mathrm{ha})$ increased on farms $\mathrm{B}$ and $\mathrm{C}$, when all corn land was double cropped compared with when no corn was double cropped. This change in $\mathrm{N}$ balance and $\mathrm{N}$ leached in the current study with $100 \%$ double cropping was in contrast to Newton et al. (2003), who reported that intensifying the cropping rotation on a dairy farm was a way to reduce the quantity of nutrients imported to a farm. Milliron (2016) also stated that nonlegume cover crops decreased $\mathrm{N}$ leaching by $70 \%$, with an average decrease of $37 \mathrm{~kg}$ of
$\mathrm{N} /$ ha. Because this study was modeled data, compared with the other studies where actual nitrogen leachate data were collected, the interpretation of the results may be somewhat limiting in this study. All farms used additional inorganic $\mathrm{N}$ fertilizer on winter annual crops. Farm B reported applying more than the recommended $\mathrm{N}$ fertilizer, which may have caused this increase in $\mathrm{N}$ losses as land double cropped increased. Crop yields also varied among farms, with farms $\mathrm{B}$ and $\mathrm{C}$ having less yields of winter annuals per hectare compared with farm A. This difference in yield likely affected the amount of nutrients removed, potentially accounting for the increase in $\mathrm{N}$ leached as double-cropped land increased from 0 to $100 \%$ (Table 3 ). In the current study, farm $\mathrm{A}$ did not have an increase in net $\mathrm{N}$ balance or $\mathrm{N}$ leached, had the largest crop yields, and applied the least $\mathrm{N}$ fertilizer on winter annuals (Table 1; Table 5). This suggests that the amount of $\mathrm{N}$ fertilizer applied to the double crops and the resulting crop yields had a greater effect on net $\mathrm{N}$ balance and $\mathrm{N}$ leached than if corn was double cropped or not.

Double cropping decreased net $\mathrm{P}$ balance consistently across farms (Table 5). This decrease in $\mathrm{P}$ balance agreed with Brown (2006), who stated that a winterannual silage planted in double-crop rotation with corn silage could remove 30 to $42 \mathrm{~kg} / \mathrm{ha} \mathrm{P}$ compared with a sole crop of corn silage. This decrease in net $\mathrm{P}$ balance was due to the fact that farms did not apply $\mathrm{P}$ fertilizer to their winter-annual crops and because more crop DM was removed through double cropping, compared with no double cropping. This removal of $\mathrm{P}$ by winter annuals is beneficial to farms with many animal units per unit of cropland, where manure application is limited based on guidelines for $\mathrm{P}$ levels in the soil and $\mathrm{P}$ removal by crops (Brown, 2006).

The quantity of $\mathrm{P}$ lost in surface runoff or in leachate in this study remained almost constant as the portion of double-cropped land increased on all farms. The winter annuals reduced erosion by an average of $57 \%$ across farms as 0 to $100 \%$ of corn land was double cropped. Winter annuals covered the soil and helped hold the soil in place during the winter months, when the soil would otherwise be bare following a corn silage crop. The small variation of $\mathrm{P}$ losses in surface runoff and leachate as intensity of double cropping increased was not expected (Table 5). Milliron (2016) stated that P lost from cropland was due to soil runoff. One explanation for why $\mathrm{P}$ losses were not large might be because in the IFSM simulation, soil $\mathrm{P}$ level was set near optimum at 30 to $50 \mathrm{mg} / \mathrm{kg}$ for all simulations. Had this value been greater to account for the longterm accumulation of soil $\mathrm{P}$ when double cropping was not used, the amount of $\mathrm{P}$ lost through erosion and runoff would have been greater. 
The percentage of $\mathrm{P}$ removed of that applied was greatest when $100 \%$ of the corn was double cropped compared with no double cropping across farms, due to the increase in crop DM removed (Table 5). The percentage of $\mathrm{P}$ removed of that applied increased across farms, with farm $\mathrm{C}$ having the greatest percentage of $\mathrm{P}$ removed of that applied compared with farm $\mathrm{B}$, which had the smallest percentage of $\mathrm{P}$ removed of that applied, and farm A being between farm B and C. When $100 \%$ of the corn land was double cropped, farm $\mathrm{C}$ actually removed more $\mathrm{P}$ than it applied, $103 \%$ by crops harvested. The fact that percentage of $\mathrm{P}$ removed was not the same across farms was a combination of the amount of $\mathrm{P}$ applied through manure and fertilizer and crop yield. Table 1 reports that farm $\mathrm{C}$ applied the least amount of $\mathrm{P}$ to corn, whereas farm $\mathrm{A}$ had the highest crop yields, which may be why farm B had least percentage of $\mathrm{P}$ removal by double cropping out of the 3 farms. This shows that for farms that do not use $\mathrm{P}$ fertilizer on winter annuals, double cropping can reduce the amount of $\mathrm{P}$ lost into the environment.

The crop production cost per unit of milk shipped increased as intensity of double-cropped land increased across farms, as reported in Table 6 . This was expected, because a winter-annual crop requires seed, fertilizer, and other inputs as an additional cropping cost. Pur- chased feed cost per unit of milk shipped also increased across farms as intensity of double-cropped land increased. This was not expected, because many farms practiced double cropping to reduce feed costs. One possible reason for this increase is that as farms went from 0 to $100 \%$ of corn land double cropped, tonnes of purchased grain increased by an average of $5.7 \%$ across farms and varied from $3.2 \%$ for farm A to $7.3 \%$ for farm B (Table 3). Rotz et al. (2002) stated that winter-annual silage often has less energy than corn silage but greater CP concentrations. As farms produced more winter-annual silage as forage, more purchased grain was needed in animal diets, which increased the purchased feed cost per unit of milk produced in the current study. Another reason is that the excess crops were produced as silage and sold, rather than harvesting excess corn as grain, as would normally be the case. If corn as grain had been harvested and used or sold as grain, instead of silage, these numbers would be different.

Net return over feed cost and net return to farm management per unit of milk increased on 2 of the 3 farms, with an average of 1.3 and $1.8 \%$, respectively, as double-cropped corn land increased from 0 to $100 \%$ (Table 6). Net return over feed cost factored purchased feed cost, crop production cost, income from crop sales,

Table 5. Net farm nitrogen $(\mathrm{N})$ and phosphorus $(\mathrm{P})$ balance, $\mathrm{N}$ leached, $\mathrm{P}$ loss, percentage of $\mathrm{P}$ removed of that applied, and erosion loss using the Integrated Farm System Model to simulate increasing percentage of corn land double cropped (DC) on 3 dairy farms in northern and western Pennsylvania

\begin{tabular}{|c|c|c|c|c|}
\hline Item & Current $^{1}$ operation & $0 \% \mathrm{DC}$ & $50 \% \mathrm{DC}$ & $100 \% \mathrm{DC}$ \\
\hline \multicolumn{5}{|l|}{ Farm A } \\
\hline Net $\mathrm{N}^{2} \mathrm{~kg} / \mathrm{ha}$ & 145.3 & 143.0 & 149.9 & 140.2 \\
\hline $\mathrm{N}$ leached, $\mathrm{kg} / \mathrm{ha}$ & 43.9 & 45.6 & 41.5 & 29.3 \\
\hline Net $\mathrm{P},{ }^{3} \mathrm{~kg} / \mathrm{ha}$ & 7.4 & 8.3 & 6.1 & 4.4 \\
\hline $\mathrm{P}$ loss in runoff and leachate, $\mathrm{kg} / \mathrm{ha}$ & 1.4 & 1.6 & 1.4 & 1.5 \\
\hline $\mathrm{P}$ removed of that applied, ${ }^{4} \%$ & 86 & 84 & 89 & 93 \\
\hline Erosion loss ${ }^{5} \mathrm{~kg} / \mathrm{ha}$ & 3,204 & 3,799 & 2,546 & 1,961 \\
\hline \multicolumn{5}{|l|}{ Farm B } \\
\hline Net $N, \mathrm{~kg} / \mathrm{ha}$ & 159.4 & 155.2 & 169.9 & 186.2 \\
\hline $\mathrm{N}$ leached, kg/ha & 66.8 & 67 & 68.3 & 72.9 \\
\hline Net $P, \mathrm{~kg} / \mathrm{ha}$ & 9.5 & 10.1 & 8.8 & 7.7 \\
\hline $\mathrm{P}$ loss in runoff and leachate, $\mathrm{kg} / \mathrm{ha}$ & 1.2 & 1.4 & 1.1 & 1.1 \\
\hline $\mathrm{P}$ removed of that applied, $\%$ & 67 & 65 & 70 & 74 \\
\hline Erosion loss, $\mathrm{kg} / \mathrm{ha}$ & 2,485 & 3,152 & 1,727 & 922 \\
\hline \multicolumn{5}{|l|}{ Farm C } \\
\hline Net $N, \mathrm{~kg} / \mathrm{ha}$ & 88.2 & 81.9 & 94.6 & 107.9 \\
\hline $\mathrm{N}$ leached, kg/ha & 34 & 33.2 & 35 & 37.7 \\
\hline Net $P, k g / h a$ & 1.7 & 2.2 & 1.2 & 0.6 \\
\hline $\mathrm{P}$ loss in runoff and leachate, $\mathrm{kg} / \mathrm{ha}$ & 1.3 & 1.4 & 1.2 & 1.4 \\
\hline $\mathrm{P}$ removed of that applied, $\%$ & 97 & 95 & 99 & 103 \\
\hline Erosion loss, $\mathrm{kg} / \mathrm{ha}$ & 3,049 & 3,908 & 2,559 & 1,895 \\
\hline
\end{tabular}

${ }^{1}$ Average parameters used in the Integrated Farm System Model representing each farm during 2016 and 2017.

${ }^{2}$ Total $\mathrm{N}$ added to fields minus total $\mathrm{N}$ removed by crops divided by land area cropped.

${ }^{3}$ Total $\mathrm{P}$ added to fields minus total $\mathrm{P}$ removed by crops divided by land area cropped.

${ }^{4}$ Percentage of $\mathrm{P}$ added to fields that was removed by crops.

${ }^{5}$ Soil eroded or lost from field. 
Table 6. Changes in crop production cost, purchased feed cost, total feed cost, net return over feed cost, and return to management per hundredweight (cwt; $45.36 \mathrm{~kg}$ ) of milk shipped using the Integrated Farm System Model to simulate increasing percentage of hectares double cropped (DC) on 3 dairy farms in northern and western Pennsylvania

\begin{tabular}{|c|c|c|c|c|}
\hline Item & Current $^{1}$ operation & $0 \% \mathrm{DC}$ & $50 \% \mathrm{DC}$ & $100 \% \mathrm{DC}$ \\
\hline \multicolumn{5}{|l|}{ Farm A } \\
\hline Crop production cost, $\$ /$ cwt & 3.21 & 3.16 & 3.30 & 3.44 \\
\hline Purchased feed cost, $\$ / \mathrm{cwt}$ & 4.51 & 4.49 & 4.55 & 4.61 \\
\hline Total feed cost, $\$ /$ cwt & 7.72 & 7.65 & 7.85 & 8.04 \\
\hline Net return over feed costs, ${ }^{2} \$ / \mathrm{cwt}$ & 11.58 & 11.45 & 11.77 & 12.04 \\
\hline Net return to farm management, ${ }^{3} \$ / \mathrm{cwt}$ & 9.38 & 9.24 & 9.58 & 9.85 \\
\hline \multicolumn{5}{|l|}{ Farm B } \\
\hline Crop production cost, $\$ /$ cwt & 5.46 & 5.26 & 5.78 & 6.32 \\
\hline Purchased feed cost, $\$ /$ cwt & 4.60 & 4.63 & 4.64 & 4.74 \\
\hline Total feed cost, $\$ /$ cwt & 10.06 & 9.89 & 10.42 & 11.07 \\
\hline Net return over feed costs, $\$ /$ cwt & 10.78 & 10.69 & 10.82 & 10.82 \\
\hline Net return to farm management, $\$ / \mathrm{cwt}$ & 8.25 & 8.15 & 8.30 & 8.31 \\
\hline \multicolumn{5}{|l|}{ Farm C } \\
\hline Crop production cost, $\$ /$ cwt & 6.05 & 5.70 & 6.36 & 7.02 \\
\hline Purchased feed cost, $\$ /$ cwt & 4.67 & 4.67 & 4.71 & 4.83 \\
\hline Total feed cost, $\$ /$ cwt & 10.71 & 10.37 & 11.08 & 11.85 \\
\hline Net return over feed costs, $\$ /$ cwt & 11.17 & 11.14 & 11.10 & 10.86 \\
\hline Net return to farm management, $\$ / \mathrm{cwt}$ & 8.65 & 8.61 & 8.58 & 8.36 \\
\hline
\end{tabular}

and cost of labor required for feeding crops to cows. The net return over feed cost was a better representation of how each farm was affected financially by double cropping than purchased feed cost, because it accounted for the extra feed sold and the extra grain purchased. The average net return over feed cost per unit of milk increased for farms when more corn land was double cropped because of the excess forage sold off the farm (Table 3). Net return to management per unit of milk evaluated how total farm income was affected by intensity of double-cropped land. Except for farm $\mathrm{C}$, net return over feed cost and net return to management increased as intensity of double-cropped land increased. Farm $\mathrm{C}$ had a negative net return over feed cost per unit of milk of $2.5 \%$ and a negative net return to farm management per unit of milk of $2.9 \%$, which showed that double cropping did not benefit farm C economically in this simulation (Table 6). One possible reason farm $\mathrm{C}$ did not benefit from double cropping was because it had the lowest winter-annual silage yield (Table 1) and the smallest percentage increase in forage sold, $23 \%$ (Table 3), as intensity of double-cropped land increased from 0 to $100 \%$, compared with farms A and $\mathrm{B}$ that had a 37 and $62 \%$ increases, respectively.

Table 7 shows the economic impact of a $30 \%$ feed price decrease and a 30\% feed price increase, while holding all other model inputs constant. The 2 scenarios for the feed price decrease and feed price increase also included double-cropped corn and no double cropping. For the double-cropped scenario, the land area that each farm was currently double cropping was used (Table 1). Feed prices used in the simulations are also reported in Table 1 . When feed prices were increased by $30 \%$ with double cropping compared with current operation, crop production cost per unit of milk increased by an average of $0.8 \%$ across farms, even though double-cropped area did not change. This increase was due to the cost of insurance for stored feeds. As the value of crops produced for feed increased, the premium for insurance for the stored feed increased as well.

When feed prices were decreased by $30 \%$, with double cropping compared with no double cropping, crop production costs per unit of milk changed by $1.7,3.8$, and $6.0 \%$ for farms A, B, and C, respectively (Table 7). When feed prices were increased by $30 \%$, with double cropping compared with no double cropping, purchased feed cost per unit of milk remained almost the same at $0.4,-0.5$, and $0 \%$ for farms $\mathrm{A}, \mathrm{B}$, and $\mathrm{C}$, respectively. This was unexpected because many farms double crop as a way to reduce feed cost. Rotz et al. (2002) reported that winter-annual silage had less energy but was greater in $\mathrm{CP}$, so more purchased grain may have been needed to balance the energy in the animal diets. Also, the excess crops were produced as silage, rather than harvesting excess corn as grain, as would normally be the case.

When feed prices decreased by $30 \%$ and double cropping was compared with no double cropping, the net 
Table 7. Evaluating the economic impact of double cropping (DC) and no double cropping (NDC), along with a $30 \%$ feed price decrease (FPD) and a 30\% feed price increase (FPI), on crop production cost, purchased feed cost, total feed cost, net return over feed cost, and return to management per hundredweight (cwt; $45.36 \mathrm{~kg}$ ) of milk shipped using the Integrated Farm System Model to simulate 3 dairy farms in northern and western Pennsylvania

\begin{tabular}{|c|c|c|c|c|c|}
\hline Item & $\begin{array}{c}\text { NDC } \\
30 \% \text { FPD }\end{array}$ & $\begin{array}{c}\text { DC } \\
30 \% \text { FPD }\end{array}$ & $\begin{array}{c}\text { Current } \\
\text { operation }^{1}\end{array}$ & $\begin{array}{c}\text { NDC } \\
30 \% \text { FPI }\end{array}$ & $\begin{array}{c}\mathrm{DC} \\
30 \% \mathrm{FPI}\end{array}$ \\
\hline \multicolumn{6}{|l|}{ Farm A } \\
\hline Crop production cost, $\$ /$ cwt & 3.13 & 3.19 & 3.21 & 3.18 & 3.23 \\
\hline Purchased feed cost, $\$ /$ cwt & 3.18 & 3.20 & 4.51 & 5.68 & 5.69 \\
\hline Total feed cost, $\$ /$ cwt & 6.32 & 6.38 & 7.72 & 8.86 & 8.93 \\
\hline Net return over feed costs, ${ }^{2} \$ /$ cwt & 11.89 & 11.97 & 11.61 & 11.01 & 11.23 \\
\hline Net return to farm management, ${ }^{3} \$ / \mathrm{cwt}$ & 9.68 & 9.77 & 9.41 & 8.81 & 9.03 \\
\hline \multicolumn{6}{|l|}{ Farm B } \\
\hline Crop production cost, $\$ /$ cwt & 5.23 & 5.43 & 5.46 & 5.28 & 5.52 \\
\hline Purchased feed cost, $\$ /$ cwt & 3.29 & 3.27 & 4.60 & 5.83 & 5.81 \\
\hline Total feed cost, $\$ /$ cwt & 8.52 & 8.70 & 10.06 & 11.11 & 11.33 \\
\hline Net return over feed costs, $\$ /$ cwt & 11.20 & 11.17 & 10.78 & 10.04 & 10.21 \\
\hline Net return to farm management, $\$ /$ cwt & 8.66 & 8.64 & 8.25 & 7.50 & 7.67 \\
\hline \multicolumn{6}{|l|}{ Farm C } \\
\hline Crop production cost, $\$ /$ cwt & 5.66 & 6.01 & 6.04 & 5.73 & 6.08 \\
\hline Purchased feed cost, $\$ /$ cwt & 3.31 & 3.31 & 4.67 & 5.93 & 5.91 \\
\hline Total feed cost, $\$ /$ cwt & 8.98 & 9.32 & 10.71 & 11.66 & 11.99 \\
\hline Net return over feed costs, $\$ /$ cwt & 10.71 & 10.62 & 11.17 & 11.24 & 11.39 \\
\hline Net return to farm management, $\$ / \mathrm{cwt}$ & 8.18 & 8.10 & 8.65 & 8.71 & 8.87 \\
\hline
\end{tabular}

return over feed costs per unit of milk changed by 0.7 , -0.2 , and $-0.9 \%$ for farms $\mathrm{A}, \mathrm{B}$, and $\mathrm{C}$, respectively (Table 7). The net return to management per unit of milk changed by $0.9,-0.2$, and $-1.0 \%$ for farms A, B, and $\mathrm{C}$, respectively. Farm $\mathrm{A}$ on the other hand, still had an economic advantage when double cropping was compared with no double cropping in the $30 \%$ price decrease, because it produced grain crop silage at a lower cost per tonne, compared with farms A and B (Table 4). The change in return over feed costs and net return to management for farms $\mathrm{B}$ and $\mathrm{C}$ as feed prices decreased highlighted the effect that the COP of crops has to the economic return to farms. However, this negative net return over feed cost and net return to management for farms $\mathrm{B}$ and $\mathrm{C}$ was unexpected because both farms produced grain crop silage for less cost than the purchased grain crop silage price of $\$ 130$ per tonne of DM (Table 4).

When feed prices increased by $30 \%$ and double cropping was compared with not, the net return over feed costs per unit of milk produced changed by 2.0, 1.6, and $1.3 \%$ for farms $\mathrm{A}, \mathrm{B}$, and $\mathrm{C}$, respectively (Table 7). The net return to farm management per unit of milk changed by $2.5,2.3$, and $1.8 \%$ for farms A, B, and $\mathrm{C}$, respectively. When farms were able to keep the COP for winter-annual silage lower than the cost of a compliment forage, double cropping was a profitable option for dairy farmers. Our data agree with what Borchers et al. (2014) stated - as commodity prices increased, farmers increased the land area that they double cropped.

\section{CONCLUSIONS}

Double cropping $100 \%$ of corn land compared with no double cropping improved total DM yield by an average of $19 \%$ across farms. Soil erosion and P lost were reduced across all farmland. Double cropping increased net return over feed cost and net return to management, given the feed prices of 2016 and 2017. However, when feed prices were decreased by $30 \%$, net return over feed cost and net return to management were decreased for 2 of the 3 farms. Crop yields played an important role in reducing the $\mathrm{COP}$ of crops produced by each farm. Double cropping could benefit a dairy farm in this region when good crop production is maintained or during a time of average to high feed prices.

\section{ACKNOWLEDGMENTS}

The authors acknowledge funding from USDA Northeast SARE, Burlington, VT (LNE16-354R) and the USDA-NIFA (PSU \# 4647). The authors have not stated any conflicts of interest. 


\section{REFERENCES}

Beegle, D. B., L. E. Lanyon, and J. T. Sims. 2002. Nutrient balances. Pages 171-192 in Agriculture, Hydrogeology, and Water Quality. P. M. Haygarth and S. C. Jarvis, ed. CABI Publ., New York, NY. https://doi.org/10.2113/3.2.726.

Borchers, A., E. Truex-Powell, S. Wallander, and C. Nickerson. 2014. Multi-cropping practices: Recent trends in double cropping. Economic Information Bulletin Number 125. USDA, Washington, DC.

Brown, B. D. 2006. Winter cereal-corn double crop forage production and phosphorus removal. Soil Sci. Soc. Am. J. 70:1951-1956. https://doi.org/10.2136/sssaj2005.0288.

Collar, C., and A. Gene. 2001. Harvest stage effects on yield and quality of winter forage. Pages 133-142 in Proc. 31st California Alfalfa Forage Symp. Univ. California-Davis, Davis, CA.

Hanchar, J. J., Q. M. Ketterings, T. Kilcer, J. Miller, K. O'Neil, M. Hunter, B. Verbeten, S. N. Swink, and K. J. Czymmek. 2015. Double cropping winter cereals for forage following corn silage: Costs of production and expected changes in profit for New York dairy farms. Cornell Field Crops. Accessed Mar. 2018. http:// blogs.cornell.edu/whatscroppingup/2015/07/13/double-cropping -winter-cereals-for-forage-following-corn-silage-costs-of-production -and-expected-changes-in-profit-for-new-york-dairy-farms/.

Harper, M. T., J. Oh, F. Giallongo, G. W. Roth, and A. N. Hristov. 2017. Inclusion of wheat and triticale silage in the diet of lactating dairy cows. J. Dairy Sci. 100:6151-6163. https://doi.org/10.3168/ jds.2017-12553.

Heggenstaller, A. H., R. P. Anex, M. Liebman, D. N. Sundberg, and L. R. Gibson. 2008. Productivity and nutrient dynamics in bioenergy double-cropping systems. Agron. J. 100:1740-1748. https:// doi.org/10.2134/agronj2008.0087.

Howarth, R. W., A. Sharpley, and D. Walker. 2002. Sources of nutrient pollution to coastal waters in the United States: Implications for achieving coastal water quality goals. Estuaries 25:656-676. https: //doi.org/10.1007/BF02804898.

Jemison, J. M., H. M. Darby, and S. C. Reberg-Horton. 2012. Winter grain-short season corn double crop forage production for New England. Agron. J. 104:256-264. https://doi.org/10.2134/ agronj2011.0275.

Kennelly, J. J., and Z. G. Weinberg. 2003. Small grain silage. Pages 749-779 in Silage Science and Technology, Agronomy Monograph. Am. Soc. Agron., Crop Sci. Soc. Am., Soil Sci. Soc. Am., Madison, WI. https://doi.org/10.2134/agronmonogr42.index

Milliron, R. 2016. Conserving nitrogen from fall dairy manure applications when coupled with winter annuals before corn silage. MS Thesis. Pennsylvania State Univ., University Park, PA.
Newton, G. L., J. K. Bernard, R. K. Hubbard, J. R. Allison, R. R. Lowrance, G. J. Gascho, R. N. Gates, and G. Vellidis. 2003. Managing manure nutrients through multi-crop forage production. J. Dairy Sci. 86:2243-2252. https://doi.org/10.3168/jds.S0022 $-0302(03) 73815-6$

Ranck, E. J., L. A. Holden, and K. J. Soder. 2019. Short Communication: Evaluating feed cost, income over feed cost, and the cost of production for milk and crops on 4 case study farms that double cropped winter annual silage and corn silage for 2 years in northern and western Pennsylvania. Appl. Anim. Sci. 35:74-82. https:/ /doi.org/10.15232/aas.2018-01792.

Rotz, C. A., M. S. Corson, D. S. Chianese, F. Montes, S. D. Hafner, H. F. Bonifacio, and C. U. Coiner. 2018. The Integrated Farm System Model-Reference Manual-Version 4.4. Accessed May 2018. https://www.ars.usda.gov/ARSUserFiles/80700500/reference\%20 manual.pdf.

Rotz, C. A., G. H. Kamphuis, H. D. Karsten, and R. D. Weaver. 2007. Organic dairy production systems in Pennsylvania: A case study evaluation. J. Dairy Sci. 90:3961-3979. https://doi.org/10.3168/ jds.2006-527.

Rotz, C. A., G. W. Roth, and W. L. Stout. 2002. Economic and environmental implications of small grain production and use on Pennsylvania dairy farms. Appl. Eng. Agric. 18:417-428. https:// doi.org/10.13031/2013.8752.

Rotz, C. A., L. D. Satter, D. R. Mertens, and R. E. Muck. 1999. Feeding strategy, nitrogen cycling, and profitability of dairy farms J. Dairy Sci. 82:2841-2855. https://doi.org/10.3168/jds.S0022 $-0302(99) 75542-6$

USDA, NASS-Northeastern Region Office (National Agricultural Statistics Service). 2013. Pennsylvania Agriculture Statistics. Pennsylvania: Average Cash Rent Per Acre, By County, 2012-2013. USDA, Washington, DC.

Wolf, C. A. 2012. Dairy farmer use of price risk management tools. J. Dairy Sci. 95:4176-4183. https://doi.org/10.3168/jds.2011-5219.

\section{ORCIDS}

L. A. Holden 10 https://orcid.org/0000-0002-7602-1890

C. A. Rotz @ https://orcid.org/0000-0001-6668-4319

K. J. Soder (1) https://orcid.org/0000-0001-6331-243X 